\title{
GLOBALISATION AND MUSLIM MINORITIES: INTEGRATION AND IDENTITY DIALECTICS IN THE WEST
}

\author{
Asif Mohiuddin*
}

\begin{abstract}
In much of the popular literature, globalisation is frequently associated with an increasing economic integration. However, from the perspective of Muslim minorities, globalisation has led to phenomenal changes in the processes of integration and identity construction that have resulted in a flourishing of composite discourses and narratives on integration and identity. This paper explores the issues related to Muslim minorities in the context of globalisation. While examining the issues related to Muslim immigration and integration, it attempts to understand how far the policies of immigration and integration have bolstered insecurity and exclusion within the multicultural societies in the West. Furthermore, this paper analyses the emergence of multiple identities among Muslim minority groups in response to discriminatory policies and practices. Finally, in order to situate the Muslim minorities in an endless pursuit of developing an open, free and diverse political community, the paper focuses on a meaningful dialogue that attempts to promote inclusion within the society.
\end{abstract}

Keywords: Globalisation, Muslim minorities, identity, policies, immigrants and multiculturalism.

\section{Introduction}

Among the most fascinating issues at the turn of the twenty-first century one of particular importance is the phenomenon of globalisation. ${ }^{1}$ Globalisation or in its most literal sense, the international integration, is not new, though. For centuries, people - and later institutions - have interacted with each other through crossborder processes such as inter-regional trade, population migration, and the technological dissemination. In the present era, globalisation is indeed one of the hotly contested concepts. ${ }^{2}$ For some theorists, it has lead to dramatic changes in the structure of national and international markets. According to one line of argument, globalisation ushers in the concepts of freedom, peace and democracy. Some authors present globalisation as beneficial, generating economic development, democratic liberalisation and a new era in the development of civilisation. Critics point out that neoliberal policies have created widest economic disparities between the people. In addition, they see globalisation as an inexorable force that undermines democratic values and cultural homogenisation. ${ }^{3}$

The rise in a global interdependence and the compression of space and time have led to what should be called an age of uncertainty. This can be said to have started 
with the dissolution of the Soviet Union that produced a spectacular flow-on effect all over the world. Among many other factors, it triggered the transformation of entire world political state of affairs and alliances across the world. While the impact of the phenomenon should not be exaggerated, it is clear that most of the world is facing immigration on an unprecedented scale. At the same time, on the one hand, the rise in global migration is seen as a threat to identity. ${ }^{4}$ On the other hand, the racialised framings on the current migrations are producing an intense backlash in many countries across the globe. The complexity of the situation has promoted insecurities, and skepticism among Western citizens. In response, they have developed an acute alertness to the movement of people and their cultural beliefs. The expressions of unrestrained ethnocentrism, cultural, and even racial hatred, have intensified racism in many Western societies at the same time as many minority populations, in particular Muslims, have been targeted. ${ }^{5}$

In the recent years, the issue of minority rights has become very prominent. In the same vein, the claims for separate identities based on religion, ethnicity or tradition have also become very evident. The phenomenon of globalisation in the context of immigration has defined the world in terms of insecurity, fear, and terror. Due to the underlying impact of September 11, the structure of nations, ethnic groups, and religions has been radically transformed. ${ }^{6}$

The situation of Muslim minorities in the West is not altogether very different, but it presents a complex view in terms of future developments. The Muslim minority status in multicultural societies has led Muslims living in the West in different directions. One of the directions is conceived as defensive and centered on the cultural reflex of self-protection and the sense of belonging vis-à-vis the surrounding ambience. The second reflects on the deeper understanding of what it means to be a Muslim in a non-Muslim majority country. The two attitudes are not necessarily incompatible, but they broadly give way to profoundly divergent outcomes. The first one seems quite unavoidable in a sense that the inherent characteristic of survival cannot be sidestepped. Any legitimate identity functions independently of exclusive forces. However, the sense of alienation can also engender feelings of intense seclusion that might end up denying the positive values and human virtues of others. Therefore, the issue demands serious reflection on how to ascertain the appropriate balance between particularity and cultural variance on the one hand, and universality and human state on the other. Given the problem stated above, this paper attempts to analyse the issues related to Muslim minorities with a view to position them towards a dialogical path that is generous, respectful and inclusive. 


\section{Immigration of Muslims into Europe and America}

The rapid movement of populations is one of the most consequential developments in the contemporary era of globalisation. In particular, the rapid settlement of Muslim communities into the Western societies has raised many questions about the alteration of culture and its impact on identity. For Chamsy el-Ojeili and Patrick Hayden, migration changes the structure of community and brings cultural transformation and dislocation. Accordingly the superior culture impinges on smaller traditions and alters them. Therefore, the issue of immigration raises many questions regarding the protection of cultural diversity in these societies. It is striking to observe that the framework of analysis of Islam in all Western societies is closely associated with the immigration debate. Immigration remains the top issue in terms of its importance within the broader context of Muslims in the West. ${ }^{7}$

Studies on Muslim immigration to Europe and America have revealed a number of interesting facts. In order to cope with temporary labor shortages and a chronic demographic crisis, the main motivation behind global migrations is the non-accessibility to certain cultural and informational resources in the countries of origin. ${ }^{8}$ Richard T. Antoun contends that most of the works on migration focus on labor migration and on the economic and social implications of migration. Little attention has been given to international migration for education. ${ }^{9}$ Generally, students migrate in pursuit of seeking education to gain extraordinary skills in more developed educational institutions. Apart from that, migration has united people of different ethnicities and historical backgrounds possessing a common immigrant origin. For example, in the case of France, Belgium and the Netherlands, the majority of immigrants are from Morocco. Muslims of Turkish descent constitute $70 \%$ of the total population of Germany. In the United Kingdom, most of the Muslims are from South Asian countries and majority of Muslims in Greece are from Abania. ${ }^{10}$ Muslims in the United States of America are the most racially diverse religious groups. Islam acts as a unifying force among Muslim groups and each of them expresses it differently. ${ }^{11}$

As a result of their class predicament, most Muslims tend to be economically and politically marginalised. Similarly the rates of employment are quite low in several European countries including Germany, France, Spain and the Netherlands. ${ }^{12}$ After the economic crisis of the early 1970s, immigration in Europe became a legal and security issue and created a conflict between those who wanted to maximise immigration control sovereignty and state actors that defended immigrant rights. Following the dramatic loss of state control, EU member states cooperated on immigration policy and other political issues. ${ }^{13}$ 
The arrival of increasing numbers of extra-regional immigrants created a lot of skepticism concerning terrorism and radical extremism. These changes even forced countries such as Netherlands and Germany to restrict further influx of foreigners. The foreigners' law in Germany disclosed the reformation of policies based on an active integration framework. French political stakeholders, in response to the gradual increase of Muslim population, called for a 'selective immigration' (immigration choisie), and paid less attention to 'imposed' immigration (immigration subie). 'Imposed' immigration necessitated a reduction of asylum seekers and family reunification, and 'selective' migration focused on non-EU workers. ${ }^{14}$ In Sweden, the increasing flow of refugees prompted the government to acknowledge the larger labor migrant category for a gentle and humane immigration policy towards family reunification. ${ }^{15}$

In Britain, the British Nationality Act (1948) gave rights of settlement and citizenship to citizens of former colonies in the United Kingdom. The largest group of British Muslims today is predominantly from Pakistan (residing in northcentral England, a region known for the production of textiles), Bangladesh and India. ${ }^{16}$ With regard to the fact that neither Canada nor the United States had any colonial interests in the beginning, the nature of immigration into North America as opposed to Europe has been quite distinct. Regardless of whether minorities had political citizenship, they were not considered full and equal citizens and were excluded from the national conversation. Even with liberal immigration policies, Canada and the United States have also regarded immigrants as outsiders. However, Canada has nurtured a majority political culture in which new immigrants are required to enter into the political nationality as equal citizens. Compared to the Native Americans, immigrants have been given small security benefits. ${ }^{17}$ In short, the immigration policies adopted by various citizenship regimes across Europe and America appear to be increasingly subversive as reflected through stricter immigration policies.

\section{Muslim Integration and the Policies of Exclusion}

The Muslim minority integration is one of the most overarching issues in the immigration debate in Europe and America. Western policymakers are attempting to develop minority policies and services that respond to individuals and are relevant to their communities. The complexity of ways in which these issues are addressed reveals both the multifaceted goals of governments and the dilemmas they confront when they seek to assimilate new groups into their societies. ${ }^{18}$ The visibility of Muslim communities and the demographic changes have aggravated public anxieties about immigration of people. Furthermore, the unwillingness of Muslim minorities to integrate has projected them as a security threat to the 
existing political structures in the West. In response to this situation, Western political establishments have developed more restrained policies towards Muslims as a religious minority. Research suggests that the number of Muslims in Europe has grown from 29.6 million in 1990 to 44.1 million in 2010. Pew forum on religion and public life estimates that by 2030, Muslims will number around 8 percent of Europe's population. ${ }^{19}$ The Council on American Islamic Relations (CAIR) has published surveys estimating the Muslim population at 6-7 million in the United States. ${ }^{20}$ For many Europeans and Americans, the concerns related to the growth of Muslim populations, security fears and identity issues, have united to form an impression that Muslims are politically exceptional, culturally unreasonable and theologically alien. Throughout history, the policies of integration adopted by many Western nations have been based on the idea of multiculturalism. Multiculturalism, for Modood, constitutes a two-way process of integration but it is taken to work differently for different groups. This is because each group is distinct, and thus integration cannot consist of a single process. The 'culturalism' refers to the understanding that the groups in question are likely not just to be marked by newness or socio-economic context but by certain forms of group identities. ${ }^{21}$ Multiculturalism recognises groups and people at the level of identities, ethnicities, and religion, including diasporic associations and political actions. This means that multiculturalism fosters different plans for accommodating minorities into specific societies.

As the number of immigrants continued to rise, the multicultural policy underwent transformation. Subsequently, the approaches towards integration also changed dramatically. The multicultural approach towards integrating minorities in the United Kingdom was similar to that of the Netherlands. Following the 9/11 terrorist attacks in the US, Madrid and London (7/7 and 21/7), the legal system in the United Kingdom made Muslims more vulnerable in a sense that the discrimination exacerbated against them with forms of colour racism and cultural racism..$^{22}$ The criticism against the multicultural model escalated following the London terrorist attacks in 2005, and impelled people to question the very possibility of cultural difference and the imposition of an ideal British citizenship.

In the Netherlands, Muslims and their religious identity values were devalued by large parts of the majority. ${ }^{23}$ In the beginning, multiculturalism was the explicit policy of the Dutch government and much of the state policy was thus oriented towards assisting minorities with difficulties in education and in the labor market. But in the light of present integration policy, the growing assumption is that the unwise application of multicultural policies was merely to confirm to the notion of political correctness. In this context, the Dutch government enacted laws which emphasised the adoption of Dutch culture and assimilation to a common set of values. 
In Germany, there are over three million Muslims, which makes them close to three percent of the total population of 82 million. ${ }^{24}$ The new citizenship law enacted in 2000 appears to be more inclusionary, although still limited, in the sense that it provides German citizens of migrant origin with opportunities in civil, social, political, cultural and economic rights. However, the general requirement of having to renounce one's former nationality continues to prevent some Muslim minority communities, including the German-Turks, from integrating. ${ }^{25}$ It has become a requirement for immigrants to participate in integration courses where they are required to obtain general knowledge on Germany, the state system, and the German language.

Governments have sought to restrict practices comprehended as opposing national or liberal democratic principles and norms, especially those that condone violence and undermine gender equality. For instance, in Denmark, it is a necessary prerequisite to sign a document that necessitates mutual respect and tolerance for individual freedoms and gender equality. The oppressive policies related to religious headwear for women have proved very factious. In France, the immigrants are required actively to take on the French culture, including the French language, and participate in political life. In this regard, immigrants become part of the French nation as individuals, not as groups having a common ethnicity or religion. ${ }^{26}$ The imposition of stricter laws banning burqa and other forms of face covering in public had the most far-reaching impact on Muslim integration. On April 11, 2011, France implemented a law that banned wearing any form of face coverings in public. The implementation was seen to ensure the promotion of public order and secularism. However, in implementing this law many basic and fundamental rights have been restricted. In terms of being a member state of the European Union, France does not possess any legal authority to implement laws banning religious freedom but it is also subject to the minimum criteria of equality and human rights as stated in the European Convention on Human Rights. ${ }^{27}$ As Gerhard van der Schyff and Adriaan Overbeeke point out:

Article 9(1) ECHR guarantees everyone the right to freedom of thought, conscience and religion in public and private, while Article 9(2) provides that any interference with such protection must be prescribed by law, be in the pursuit of a legitimate aim and necessary in a democratic society in order to be justified. ${ }^{28}$

In order to justify the interference, the state must ensure that the interference is legal and directed at a legitimate aim. On the contrary, the European Court of Human Rights has been castigated for rejecting "neutral" laws of general applicability as evidences for interference, because in doing so, it arguably ignores the immanent experience of the plaintiff. Moreover, the court defends mainstream religions over minorities by acknowledging the non-applicability of neutral laws that might cause interference. In short, Article 9 of the European Convention 
on Human Rights presents a compelling debate on diversity of interpretation. Despite the growing skepticism, the court is willing to determine a legitimate aim on the basis of any legal argument that contributes to a public good. However, the court's strict position on neutral laws and the margin of appreciation leave significant opportunity for governments to discriminate against minorities.

For countries like the United States and Canada, the uniqueness of the minorities is the most remarkable feature that has been recognised. Canada, for example stresses the protection and enhancement of ethnic diversity. To incorporate all the ethnic groups, Canadians focus on civic assimilation and ethnic identities. Furthermore, Canada has adopted multiculturalism as a state policy, giving due importance to ethnic cultural diversity, towards integrating minorities. ${ }^{29}$ Despite the restricted policies, the Muslim minority communities have reacted with resilience, political advocacy and profound intellectual and psychological activism. While protecting the unity of the American social and legal establishments, Muslims minorities are trying to combat discrimination and xenophobia through extensive social and political networks. From a historical point of view, Muslims in North America constitute the most diverse population, representing most of the races and ethnic groups present in the world today. Furthermore, they speak many languages and endorse a variety of social, ideological and educational viewpoints. The unprecedented and exponential growth of Muslim minority community has been quite striking. Unlike the United Kingdom, America has witnessed the immigration of middle-class professionals, educated Muslims from the Middle-East and South-Asia. ${ }^{30}$ The European countries, on the other hand, have witnessed the influx of poor and non-professional Muslims. The Socio-economic context in turn has situated the American Muslims in a better position of synthesising western culture with immigrant culture, and structured the probability of an innovative form of integration that is seen to protect the cultural heritage and their religious values. ${ }^{31}$

Among the Muslim minorities, the higher level of education and economic prosperity are the indicators of successful integration. Contrary to the general public, fewer Muslim Americans have finished their graduate school and more than one-fifth of U.S Muslims are studying in graduate colleges. With regard to financial rewards, Muslim Americans have mixed feelings. In the case of immigrant Muslims, the financial situation is better than that of the native born Muslims and in contrast with the general public, a smaller percentage of Muslims is employed full-time. ${ }^{32}$ In recent years, various Muslim public affairs groups have subsequently emerged in support of Muslims against discrimination and are voicing their concern for them in the public arena. ${ }^{33}$ Following 9/11, there has been a marked increase in the social and dialogical activism of Muslim organisations, focusing on providing direct services, opinions, and 
developing institutional networks. Although, there is scanty evidence related to the existence of coordination between the immigrant and non-immigrant groups, the prominence of an inter-organisational dialogue between these two distinct communities reveals a different perspective on this issue. The diversity exists within the Muslim communities on the basis of racial and ethnic group characteristics, socio-economic context, citizenship, and identity. In the same vein, feelings of inclusion vary by ethnic and racial identity within the group. For example, African-American Muslims are more dissatisfied than Arabs and South-Asian Muslims. They presume as if the existing socio-political scene is hostile, dangerous and against their religious beliefs. In addition, with respect to social media issues, South Asian Muslims are better projected than Arabs. The American connections to the various nations vary enormously and owing to the weak and less problematic connections to South-Asia, Americans have been very comfortable in establishing dynamic social and cultural relations with them. In other words, unlike the Middle Eastern countries, the non-existence of politically charged relations with South-Asia is one of the reasons behind the stability of this relationship. ${ }^{34}$

On the other hand, racial or ethnic divisions reflect a diversity of factors, including the immigrant assimilation and exceptional social-economic status of South-Asians and the marginalised status of African-Americans. In many ways these factors demonstrate a distinct pattern of identities that emerge through the interaction between religious and political groups. They also indicate that the Muslim subjectivity may be different in contrast to indigenous values. During the past twenty years in America, there has been a proliferation of state legislation that challenges the limited role of state in the promotion of religious expression. Lori Beaman, regarding the acrimonious relationship between church and state, argues:

...While the United States has a clear separation of church and state in its Constitution, an examination of cultural symbols reveals that church and state are intertwined to the extent that politicians frequently invoke the name of god to assist in state matters. The relationship between church and state is not solely a matter of internal law and politics, however. Church-state relations are influenced by, and themselves influence, global forces which may take the shape of international human rights declarations, the activism of internationally organised groups, or broader cultural vectors such as events that work to create a culture of fear or which demarcate a social phenomenon as a cause for concern. ${ }^{35}$ 
The relationship between church and state must be analysed in terms of statelevel legislative developments that influence the activities of religious groups within the state. However from the above discussion, it can be clearly discerned that there is a huge contradiction between what is stated in law and the ways in which the laws are enforced. This postulates the exposition of religious symbols and the constitutional framework around religion. The results show that the legislation is largely a product of the evangelical Christian movement, which stresses the inclusion of religion, and in particular, a fundamentalist group, as an important component of governance.

In some Western nations, population stability depends on immigrants who usually come from racially and ethnically diverse societies. Since the religious texture is different and changing, the state needs to counter different religious groups and defining voices that are necessary to be recognised with an aim of integrating people. The transformation of civic engagement among Muslims is also an indication of successful integration. Certain organisations have emerged for providing services and representing Muslims on political issues from time to time. From their inception, these groups were typically service oriented, providing information and religious education up to a certain level. During the 1960s these organisations started political advocacy and provided a platform for unity. In this manner, political advocacy became an inalienable part of associational life in the United States of America. ${ }^{36}$ The role played by several governmental agencies in identifying advocacy organisations in order to securitise the state against any illegal activity, has given a particular identity to Muslims. For this purpose, the US Department of justice organised many programmes and meetings, addressing issues related to terrorism and civil society. In America, the largest component of civil society is represented by religious institutions, hospitals, schools, cultural centers. Historically, these institutions have played a significant role in engaging people from different ethnicities and backgrounds. It is estimated that more than half of volunteer activity in the United States is undertaken in religious settings. Further, a wide majority of Americans are associated with religious organisations, performing important functions such as maintaining stable relations between the state and its ethnic minorities. Such institutions have a huge impact on civil society integration and the American political structures and it is through these associations that people participate in politics, organise meetings and elect governing boards.

The representation of Muslims in some countries is undermined by the problems that arise in demarcating Muslim minorities beyond their ethnic complexities. On the political level, the fragmented identities necessitate a dialogical adhesion between political establishments and religious communities. Moreover, the fragmented identities create competitive atmosphere among various associations 
and try to influence Muslim communities. In the United States, the problems of political representation do not exist but still ethnic-based communities promote division among the Muslim minorities. ${ }^{37}$

Since the US immigration policy was influenced by the $9 / 11$ terrorist attacks, the US government took strict action against non-citizens suspected of terrorism. With a view to empower the Department of Justice, the Patriot Act was signed into law by the American President in October 2001. ${ }^{38}$ Similarly, the Criminal Alien Removal Act (CLEAR), was legislated to improve the enforcement of immigration laws by applying stricter penalties on those who violate the law. ${ }^{39}$ In response, the Muslim stakeholders maintained that these policies systematically create oppressed nationalities; intense hatred and exclusion within the society. In addition, the violation of civil liberties by the media and legal organisations made Muslims more vulnerable to the physical abuses and social discrimination. Muslim minorities in America were projected as inassimilable even though a majority of them supported the adoption of American cultural values. Overall, after 9/11, the American Muslim experience changed exceptionally and in contemporary times, America is witnessing a declining power of religious structures, and rising antiMuslim sentiment. All these factors have excluded Muslims from mainstream political and social life.

\section{Muslim Identities in the West}

In the era of globalisation and insecurity, the capitalist world-view has imposed a certain form of cultural homogeneity, challenging the existence of the already surviving cultures. Consequently, this has further led to the emergence of contested identities among individuals on the basis of ethnicity, religion and race. Similarly, the global western culture has radically marginalised the individual cultures that promote distinct identities. In contemporary times, Islam is seen as such a contested macro social identity globally. ${ }^{40}$ In the words of Jocelyne Cesari:

Globalisation is a cultural process that favours the development of nonterritorialized cultures and communities based on race, gender, religion, or even lifestyle. In this respect, Islam is a powerful element in identity formation, weaving together solidarity between various groups that are separated by the constraints of diverse nations, countries and cultures. ${ }^{41}$

In recent times, the transnationality of Islam has attracted a lot of attention in different parts of the world. The transnational networks in the form of diasporic communities along with the revivalist movements emphasise the existence of 
a global nexus between Muslims living in various parts of the world. These networks include professionals, religious leaders and intellectuals who develop connections and identities that exceed national circumferences. Thus the adaptation of Islam to the new environment reveals a complex perspective in relation to the identification with global forms of Islam and national cultures.

In the post-September 11 context Islam has been projected as a threat to international security and peace. This reflects the existence of an essentialist approach in response to the confrontational situation created by the host societies in the form of exclusive policy framework. At the core of this conflict, it must be stated that the historical relationship between the Muslim World and Europe is a history filled with confrontation, appreciation, and a host of conflicting narratives. The stereotypical representation of Muslims has been crystallised through specific historical events such as violence, heresy and brutality. This perception has given rise to a discourse that presents Islam as an impediment to the world's progress towards peace and modernisation. Therefore, the minorities especially Muslims are forced to integrate at the expense of their cultural values. The idea that Islam is a serious threat to the internal security is further reinforced by the application of essentialist approaches towards minority integration. From the perspective of representation of Muslims, they are seen to act within the interstitial space between representation and the real existence of the community. ${ }^{42}$

Thus, the paradoxical status quo has obscured the relationship between the dominated and the dominating, giving rise to three possible settings: acceptance, avoidance, or resistance. ${ }^{43}$ Acceptance implies the acknowledgement of a dominant discourse. This connotes either the acceptance of cultural values and mutually acceptable choices, or the intricate complexity of agreement to disagree. Through the process of dialogue and debate it further stresses the obliteration of fear and uncertainty. A strategy of acceptance gives least importance to ethnic, religious or other identities. However, what is emphasised in empirical terms are similarities and acceptance and tolerance for Muslims and non-Muslims alike and practical solutions to real and formidable threats. It is through this process that the policies of exclusion and discrimination can be challenged in a more robust manner. Avoidance evokes a response of withdrawal from the social context and sees the socio-political environment as hostile and intolerant towards minorities. This identity perspective emphasises the removal of oneself and staying away from the public domain as much as possible. Resistance regards socio-political context as confrontational and refuses to acknowledge the status given by the majority. There also exist other forms of resistance that are centered on positive commitment to religion and progress. Muslim identity is influenced by a variety of factors including the national context, the status of different religions, the framework of acquiring nationality, and the acceptance 
and application of multiculturalism in different societies. In this way, the Muslim identities emerge in response to the dominant political and cultural discourses. In the secular context, ethnicity is seen as a more peripheral way of framing subjectivity which involves identifying oneself in terms of one's attachment to a place. Religious identity, on the other hand, denotes a form of global identity which is not affected by national boundaries. ${ }^{44}$ The separation between the two has become very prominent in the multicultural societies and now Muslims define themselves in relation to the specific secularised context which is detached from the ethnic or racial identification.

The process of globalisation which stimulates the movement of ideas and concepts beyond nation states has enormously impacted the religious identity of Muslims. The ways in which Muslims become aware of other Muslims and their experiences have nurtured a different sort of global identity among them. Since globalisation has already increased communication between people in all parts of the globe, it has led to the formation of Muslim transnational solidarity. Consequently, due to the intensified migration, Muslims living in the West are facing numerous challenges regarding traditional identities and cultural affiliations. To address these problems, they try to affirm their identities on the basis of faith. As Melanie Reddig states:

Identity affirmation is achieved by defining the meaning of being a Muslim and identifying with the global Muslim community. Migrants who have lost their social and cultural connection to the country of origin tend to favour a concept of Muslim identity which defines Islam independently of a particular cultural setting. ${ }^{45}$

The argument offered here is further substantiated by the experiences of second and third generation Muslims in the West, who see themselves excluded from the cultural roots of their parents. These Muslims experience a serious identity crisis and in order to resolve it they turn to Islam for religious and social security. Although the religious values and practices differ considerably between Muslim societies, the existence of different cultural ethos can cause problems in ascertaining the form of religious identity that can remove uncertainty resulting from the process of globalisation. Due to the inevitable fear of losing Muslim identity, independence and values in the context of western dominated globalisation, the Muslims focus on establishing a clear form of identity that protects their religious and cultural values. At the same time, culture forms an important part of the religious identity. Therefore the issue of Muslim identity can't be separated from its historical and cultural context. In this respect, Muslim identity becomes indistinguishable from the secular identity. ${ }^{46}$ Masud observes that the religious activists among Muslims are propagating education to strengthen their religious identities. By contrast, 
some consider this development as an aspect of Islamic revivalism. Eickelman regards this as a modern development which exists independently of old forms of religious understandings. ${ }^{47}$ In Great Britain, the call for separate religious schools provoked a dramatic response from the British government. The Swann report (1981), analysed the issue from three different angles; cultural pluralism, multiculturalism and cultural relativism. The report concluded that the existence of separate schools will harm and isolate the Muslims from the mainstream society. Because of viewing religion as an entity that must not have any political manifestation, the Swann report saw religious education as a matter of ethnicity and cultural identity. Likewise, in the Netherlands, the question of religious education was taken seriously by the church. The Christian schools formulated a policy for education and introduced certain conditions. The non-acceptance of conditions from the Muslim side further made policymakers to deliberate on the issue and finally they came up with a new policy initiative in the form of a paper that discussed the issue from three perspectives. The paper preferred the second approach that was based on admitting Muslim children only if there is a dialogical understanding between the two. The third approach stressed ethnic and cultural identity, permitting Islamic education only if it was culturally oriented. Ultimately, Muslims focused on establishing independent Islamic schools. ${ }^{48}$ Thus, from the above discussion, it becomes clear that religious identity is a dynamic entity that influences the personal and collective lives of the people. The preservation of cultural identity from a theological point of view was the main objective behind the establishment of independent schools for Muslim children. As a result, the acculturation process became more influential in the creation of subcultures among Muslim minority groups in the West.

In the examination of subcultures, Olivier Roy identifies tensions between five levels of identity among Muslims in Europe:

1. The transposition of a robust solidarity group based on a geographical setting.

2. A larger group or national identity, based on a common language and culture.

3. A new definition of Muslims centered on neo-ethnic relations irrespective of language and literature.

4. An innovative definition of a Muslim identity based on religious understanding, excluding culture and language.

5. The adoption of culture along Western lines and relegating faith to a subordinate position, leading to the creation of a Western subculture that is usually identified as an ethnically described category having little to do with the hereditary culture. 
The analysis of the above stated dynamic levels reveals the absence of Muslim cultural ethos in relation to ethnic national culture and religion. It demonstrates the effectiveness of the solidarity of a native group which provides the motivation for emigration. In Britain, the phenomenon is more prominent than in France. The citizenship regimes also shape the identities of migrants in a manner that immigrants are forced to adopt the host culture and external beliefs and rituals. In this way, the traditional-solidarity groups are more affected by the Western acculturation processes that result in their transformation and reconstruction. Cultures see transformation when people migrate to other places and when they confront other cultures, the minority identities are reduced to ethnic identities and at that point of time the ethnic culture undergoes further transformation. Hence, the global Muslim identity functions independent of any particular culture and through the process of deculturation, the universal religions lose their social authority. ${ }^{49}$

The arrival of immigrants along with their ethnic cultures in America triggered the emergence of a unique form of identity that was manifested through language, religion, music and certain family patterns. In the aboriginal countries there was no conflict between the contested patterns of identities. But, in the host countries these levels sometimes contradicted with one another. Since, subjectivity wasn't able to address the questions related to the higher group, the citizenship regimes in the West attempted to strengthen the process of acculturation by restructuring and reinventing the collective identities.

From the beginning, the American establishment formulated new policies and tried to address issues related to Muslim minorities. In 1960s, the new immigration policy recognised and preferred professionals and in this way many Muslims emigrated and became an important part of a well established American middleclass. As the immigrants arrived in increasing numbers, they started to establish Muslim institutions especially the community centers. Islamic organisations became more visible in addressing issues and establishing amicable relations with other communities. About three million Arabic speaking people constitute about one percent of the American population. This Arab community exhibits diversity in terms of its religious, ethnic, tribal and national identities. In response to these policies, Arab-Americans themselves fashioned their identities through the experiences, places of settlement, dialogical understanding, and the diversity of the community. The prejudice and intense hatred towards Muslims has been also quite influential in shaping the identities of people. ${ }^{50}$ The establishment of the Arab-American institute in 1985 urged Muslims to take active part in civic life and politics. ${ }^{51}$ In addition, the institute stressed creating a sense of national identity and further encouraged people to adopt American values. The council 
on American-Islamic relations (founded in 1994 to protect civil liberties of Muslims) attempted to promote justice and clarified the position of Muslims on numerous important issues. In America, the new immigrants came with a distinctive mindset and tried to negotiate their identities in a typical uncongenial ambience. While the parents wanted to keep their children within the traditional environment, the children followed a different trajectory that identified them with the growing alienation of Muslims. The Americans, on the other hand, demanded answers from Muslims regarding American values, traditions and their identity as American citizens. The complexity of identifying themselves as Americans and Muslims made many young Muslims experience hatred and discrimination.

\section{Conclusion and Policy Recommendations}

Historically, the settling of immigrants and their arrival in the Western societies increasingly challenged the policies of integration and assimilation. This was the era in which the politics of essentialism emerged as regimes and cultures responded to the long-term presence of minorities and struggled with racist and antiracist forces. Further, this lead to the emergence of an intricate psychology of insecurity among minorities and in response to this state of affairs, different identity strategies were adopted by them. The strategic responses to insecurity in the form of essentialism and retreatism were perceived as reactive in a manner that the existence of foreigners was regarded as a security threat. In multicultural societies a sense of alienation was nurtured through intensified checks and security measures forcing minorities to rethink their economic, social and political lives in their societies.

In her analysis of citizenship's exclusions in the United States, Kristen Hill Maher states that the policies towards minorities often fail to uphold the criteria stated in the Universal Declaration of Human Rights. The violations have been clearly documented by the Human rights organisations. The violation of labor rights, the failure of state intervention and the use of threats in order to preempt organised demands are ample evidences regarding the prevalence of injustice in these societies. Current policies related to deportation, detention and asylum procedures, have further violated rights. While analysing these policies, it can be stated that the political culture in these societies subordinates the universal brotherhood to citizenship as a basis for rights. ${ }^{52}$ In other words, the violations and vulnerabilities of rights in the context of the inimical acts and policies, illustrate the existence of a cultural logic that regards human rights as entitlements exclusive to citizens.

Such policy initiatives have forced minorities to take either a retreatist or essentialist position as responses to insecurity. These positions can be avoided 
if both structural and psychological factors are addressed. This can be achieved by analysing the lived experiences of people and how such experiences are redacted in relation to the socio-economic and political settings in society. Thus automatically people can utilise the resources by challenging the status quo and getting dialogically involved with other community members. In addition, the dialogical perspective gives equal advantage to dominant voices by contextualising the rights given to the dominant group. Hence these rights are to be examined within the framework of the Western metanarratives and as such they act as analytical tools in the understanding of other complex phenomena. The majority and minority community members can thus exceed their limitations through a sustained process of dialogue..$^{53}$ But the current status quo offers little prospect for the achievement of a universal human community. At the same time, globalisation obliterates the communitarian linkages through segregated groupings. Therefore, no alternative seems adequate in the context of globalisation.

Finally it would be appropriate to conclude with the following policy recommendations, which would emphasise the establishment of a viable and tolerant political community:

- The host communities must show a stronger commitment to a pluralistic cosmopolitical order in which people of all faiths and communities must contribute and continuously engage in a dialogical process that emphasises the politics of inclusion with renewed multicultural potentialities.

- The dialogical process necessitates the openness of agents to the possibility of transformation.

- The dialogical engagement entails the acceptance of distances and differences; self and other: the possibility of arriving at a common platform, even at the time of disagreement: and how much is held in common.

- To the Muslim citizens, the dialogical participation may mean having to accept and live with laws and regulations of the host societies that grant full rights and a degree of freedom of expression to non-conformists.

- Eventually, the dialogical path will provide the requisite orientation to all agents in the society along with the possibility of a commitment to a common citizenship. 


\section{Notes}

* AsifMohiuddin, Doctoral candidate from the Department of Islamic Studies, University of Kashmir, Srinigar, India. He can be contacted at asif.mohiuddin09@gmail.com.

1. Colin Mackerras, China's Ethnic Minorities and Globalisation, (London: Routledge, 2003), 1.

2. Philip G. Cerny, Rethinking World Politics: A Theory of Transnational Neopluralism, (Oxford: Oxford University Press, 2010), 27.

3. To illustrate the point that "Globalisation generates economic development," the phenomenon of globalisation is studied from three perspectives: trade, capital flow and labor flow. In terms of trade or export, the ratio between gross value of export is used as an index to evaluate the level of participation of economic bodies in the global market. The global ratio between gross export and GDP has increased from 7 percent to 19 percent today. Similarly, the amount of trade has increased sixteen-fold. Capital flow in terms of direct foreign investment comprises 6 percent of global investment. In recent decades, each nation has significantly relaxed limits on capital flow, increasing the global flow of financial capital. The trade of financial goods has increased almost 30 percent annually. At the top of this, the ratio of U.S securities and stock trade between countries to GDP has risen from 9 percent to 135.5 percent. For Manfred Steger, economic globalisation has stimulated flow of trade in goods and services, creating new linkages among national economies. This increasing amount of trade and investments under globalisation has promoted growth and created more jobs. There is a plethora of literature implicating economic globalisation in the demise of social democracy. This thesis is contested by a number of recent studies which have delivered significant insights into how the domestic institutional structures are mediating the socio- political influence of globalisation. Regarding the point that "globalisation generates a new era in the development of civilisation," hyperglobalists view globalisation as legitimate and inexorable historical process, which leads to a world order based on the market and global institutions. This process is understood as progressive and socially desirable. Globalisation is seen to destroy all previously established structures. The role of nation-state in this context is also significantly losing ground. Multinational corporations concentrate vast resources, and become main carriers of economic activity on a global scale. This creates a new era in the development of a global civilisation in which the market is integrated on a global level multinational companies are being major actors in the process and global institutions subordinate the role of nation states. See Zoran Stefanovic, "Globalization: Theoretical Perspectives, Impacts and Institutional Response of the Economy," Journal of Facta Universitatis 5, no. 3, (2008), 264-265. Mehdi Mozaffari (ed.), Globalization and the Civilizations, (London and New York: Routledge, 2002), 47. For a thorough analysis of globalisation and economic development see, Dean Baker, Gerald Epstein and Robert Pollin, Globalisation and Progressive Economic Policy, (Cambridge: Cambridge University Press, 1998. For an excellent delineation of academic discourses on globalisation see, Douglas Kellner, "Theorizing Globalization," Sociological Theory 20, no. 3 (2002), 286.

4. Lada Timotijevic and Glynis M Breakwell, "Migration and Threat to Identity," 
Journal of Community and Applied Social Psychology 10, (2000), 357.

5. For analysing the role of citizenship regimes in the context of globalisation and cosmopolitanism, see Catarina Kinvall and Paul Nesbitt-Larking, The Political Psychology of Globalization: Muslims in the West, (Oxford: Oxford University Press, 2011), 4.

6. Ibid., 9.

7. It is pertinent to note that immigration is a central issue in Europe due to the fact that majority of Muslims are either immigrants themselves or have an immigrant background. Hence any such discussion pertinent to Muslims in Europe must take place, at least in part, within the context of Muslims as immigrants in their communities. This point provides the framework through which we can understand properly the issue of Muslim immigration in Europe. Considering this as our starting point, it should be understood that the attacks of $9 / 11$ and the distinct connection between Muslim immigration and the socio-economic situation, have significantly challenged the policies of immigration in Europe. See http://www. euro-Islam.info/key.../ immigration/ (accessed on 15 February 2015). For a detailed and critical discussion on cultural globalisation, see Chamsy el-Ojeili, Patrick Hayden, Critical Theories of Globalization, (New York: Palgrave and Macmillan, 2006), 150.

8. Ulrich Beck, Natan Sznaider and Rainer Winter (eds.), Global America? The Cultural Consequences of Globalization, (Liverpool: Liverpool University Press, 2003, 155.

9. Akbar S. Ahmed and Hastings Donnan (eds.), Islam, Globalization and Postmodernity, (London: Routledge, 1994), 157.

10. See Jocelyne Cesari, et al. "Securitization and Religious divides in Europe: Muslims in Western Europe after 9/11: Why the term Islamophobia is more than a predicament than an explanation," Submission to the changing landscape of citizenship and Security $6^{\text {th }}$ PCRD of European Commission, June 1, 2006. 1012.

11. Akbar Ahmad, Journey into America: The Challenge of Islam, (Washington, DC: Brookings Institution Press, 2010), 214.

12. Cesari, et. al, op. cit. 17.

13. Terri Givens and Adam Luedtke, "The Politics of European Union Immigration Policy: Institutions, Salience, and Harmonization," The Policy Studies Journal 32, no.1 (2004), 148.

14. Ayhan Kaya, Islam, Migration and Integration, (New York: Palgrave and Macmillan, 2009), 69.

15. Pontus Odmalm, Migration Policies and Political Participation: Inclusion or Intrusion in Western Europe? (New York: Palgrave and Macmillan, 2005), 56.

16. For a nuanced discussion on Muslim integration in Europe, see Robert J. Pauly, Jr. Islam in Europe: Integration or Marginalization? (New York, Ashgate, 2004), 100.

17. Diane Sainsbury, "Immigrants' social rights in comparative perspective: welfare regimes, forms in immigration," Journal of European Social Policy 16, no. 3 (2006), 232.

18. Jonathan Laurence, The Emancipation of Europe's Muslims: The state's role in minority integration, (New Jersey: Princeton University Press, 2012), 245. 
19. Brian J Grim and Mehtab S Karim, The Future of the Global Muslim Population: Projections for 2010-2030, (Washington DC: Pew Research Center, 2011), 121.

20. See Yvonne Yazbeck Haddad and Jane I. Smith (eds.), Muslim Minorities in the West Visible and Invisible, (Walnut Creek, California: Atamira Press, 2002), vi.

21. Tariq Modood, Multiculturalism: A Civic Idea, (Cambridge: Polity Press, 2013, 2nd ed.), 44-45.

22. Tariq Modood, Anna Triandafyllidou and Ricard Zapata-Barrero (eds.), Multiculturalism, Muslims and Citizenship: A European Approach, (London and New York: Routledge, 2006), 43.

23. Mieke Maliepaard, Religious Trends and Social Integration: Muslim Minorities in the Netherlands, (Amsterdam: Ipskamp Drukkers B.V, 2012), 86.

24. Tuula Sakaranaho, Religious Freedom, Multiculturalism, Islam: Cross-reading Finland and Ireland, (Leiden and Boston: Brill, 2006), 205.

25. Ayhan Kaya, op. cit. 60.

26. Kathryn Boustead, "The French Headscarf Law before the European Court of Human Rights," Journal of Transnational Law and Policy 16, no. 2, (2007), 191.

27. Lina Ragep Powel, "The Constitutionality of France's Ban on the Burqa in light of the European Convention's Arslan v. Turkey Decision on Religious Freedom," Wisconsin international law journal 31, no. 1, (2013), 129.

28. Gerhard van der Schyff and Adriaan Overbeeke, "Exercising Religious Freedom in the Public Space: A Comparative and European Convention Analysis of General Burqa Bans," European Constitutional Law Review 7, no. 3, (2011), 435.

29. Andrada Costoiu, “Modes of Minorities' Integration: Explaining Historical, Economic and Political Factors," Journal of Identity and Migration Studies 2, no. 2, (2008), 2-3.

30. Yvonne Yazbeck Haddad and Jane I. Smith, Muslim Women in America: The Challenge of Islamic Identity Today, (Oxford: Oxford University Press, 2006), 4.

31. John H. Morgan, "Islam and Assimilation in the West: Religious and Cultural Ingredients in American Muslim Experience, Journal of Religion and Society 16, (2011), 3 .

32. http://www.pewresearch.org/pubs/483/muslim-americans $\ldots$ (accessed on 1 February 2015).

33. Yvonne Yazbeck Haddad (ed.), Muslims in the West from Sojourners to Citizens, (Oxford: Oxford University Press, 2002), 169.

34. Ibid., 236.

35. Peter Beyer and Lori Beaman (eds.), Religion, Globalization and Culture, (Leiden and Boston: Brill, 2007), 391.

36. Ebrahim Moosa and Jeffrey T. Kenny (eds.), Islam in the Modern World, (London and New York: Routledge, 2014), 376.

37. Birgit Schaebler and Leif Stenberg (eds.), Globalization and the Muslim world: Culture, Religion and Modernity, (New York: Syracuse University Press, 2004), 85.

38. John W. Whitehead and Steven H. Aden, "Forfeiting Enduring Freedom for Homeland Security: A constitutional Analysis of the USA Patriot Act and the Justice Department's Anti-Terrorism Initiatives," American University Law Review 51, no. 6, (2002), 1088. 
39. Maha M. Ayesh, "The Clear Act: When the Wars on Terrorism and Immigration Collide," Tennessee Journal of Law \& Policy 2, no. 2, (2005), 1.

40. Fareed Kazmi and Sanjeev Kumar, "The Politics of Muslim Identity and the Nature of Public Imagination in India: Media and Films as Potential Determinants," European Journal of Economic and Political Studies 4, no. 1, (2011), 172.

41. Aziz al-Azmeh and Effie Fokas (eds.), Islam in Europe, (Cambridge: Cambridge University Press, 2007), 56.

42. Ibid., 53.

43. Gerard A. Postiglione, Ethnicity and American social theory, (Lanham: University Press of America, 1983), 181-2.

44. Naser Meer, Citizenship, Identity and Politics of Multiculturalism: The Rise of Muslim Consciousness, (New York: Palgrave and Macmillan, 2010), 83.

45. Tughrul Keskin, The Sociology of Islam: Secularism, Politics and Economics, (UK: Ithaca Press, 2011), 169.

46. Muhammad Khalid Masud, Armando Salvatore and Martin van Bruinessen (eds.), Islam and Modernity: Key Issues and Debates, (Edinburg: Edinburg University Press, 2009), 262.

47. According to MuhammadKhalid Masud, The recent growth of institutions of higher education in Pakistan and Malaysia illustrate the growing concern for protection of Muslim identity through mass education. He argues that the continued stress on the theological basis of religious identity by modern movements for religious education have faltered progress of a pluralistic world view. It has rather given way to religious extremism, fundamentalism and violence. In contrast to the ideal mass education theory, the exclusionist approach to religious identity has nurtured a sense of insecurity and fear of others. Dale F Eickelman completely disagrees with the scholars who identify these developments as a "revival" of the old forms of religious world view as espoused by religious activists as well. He regards them as modern developmental initiatives that are necessary for the growth of social and economic activities. See Johan Meuleman (ed.), Islam in the Era of Globalization: Muslim Attitudes towards Modernity and Identity, (New York: Routledge, 2002), 233-234. For the critique of revival of old forms of religious understanding in the context of establishment of institutions of higher learning see for instance, Dale F. Eickelman, "Mass Higher Education and the Religious Imagination in Contemporary Arab Societies", American Ethnologist, 19, no. 4 (1992), 643.

48. Johan Meuleman (ed.), op. cit. 177.

49. Olivier Roy states that in order to define a global Muslim identity one must delink Islam from any given culture in favour of a transnational and global set of patterns. There appears to be a robust relationship between deculturation and religious reformulation in a sense that when a religion is experienced not so much by a minority without relation to ethnicity and culture, it loses social authority. Thus what evolves is not religion but religiosity which describes the way in which believers build their relationship with religion. See Olivier Roy, Globalised Islam: The Search for a New Ummah, (New Delhi: Rupa and Co, 2005), 117-120.

50. Yvonne Yazbeck Haddad, Becoming American? The Forging of Arab and Muslim 
Identity in Pluralist America, (Texas: Baylor University Press, 2011), 14.

51. Ann Malaspina, The Ethnic and Group Identity Movements: Earning Recognition, (New York: Infobase Publishing, 2008), 136.

52. Alison Brysk (ed.), Globalization and Human Rights, (Berkeley: University of California Press, 2002), 21.

53. Catarina Kinvall and Paul Nesbitt-Larking, op. cit. 193. 